\title{
Michael Chamberlain,
}

Ortaçă̆’da Bilgi ve Sosyal Pratik, Şam, 1190-1350, çev. Büşra Kaya, İstanbul, Klasik Yayınları, 2014, 248 s., ISBN 978-605-5245-25-2

İslâm ilim ve kültür hayatının en özgün kurumlarından olan medresenin tekemmül etmiş bir yapı olarak ortaya çıkması onuncu yüzyıl civarıdır. Bu tarihlerden sonra Bağdat, Şam, Kahire, Mekke, Medine, İstanbul, Buhara, Semerkant başta olmak üzere çok geniş bir coğrafyada değişik türleri ortaya çıkmıştır. Medresenin ortaya çıkmasının asıl sebebi, ehl-i sünnet itikadını sağlıklı bir şekilde korumak, İslâmî ilimlerin öğrenilmesi sağlamak, dini bâtıl inançlara karşı savunmak ve toplumsal meselelere bu zaviyeden çözümler üretmektir. İslâm devletlerinin adaleti temin için sahip olması gereken bilgi, beceri ve diğer donanımları üretmek de öncelikli amaçtır. Bu gaye ile ortaya çıkan medrese, devlet ve halk arasında etle tırnak gibi olmuştur. Farklı İslâm coğrafyalarında mimarisinden personel yapısına, eğitim pratiklerinden ritüellerine, malî/vakıf yapısına ve devletle olan münasebetinde birbirine hiç benzemeyen sistemler üretilmiştir. Bu durum bu gün medrese denildiğinde aslında son derece karmaşık, anlaşılması güç bir tarihi mirasın karşısında olduğumuzu gösterir. Bu devasa karmaşık yapının koridorlarında gezinmek, söz konusu özgünlüğün ve ortaya konulan eserlerin farkında olmanın da uzağında bulunulmaktadır.

On dokuzuncu yüzyılda yaşanan modernleşme sancısının ürettiği sahte dinbilim çatışmasının zehirli ürünü olarak ortaya çıkan "medreselerin gerilemesi" algısı genel kabul haline gelmiş, sorgulama ve araştırmaların önünü tıkamıştır. Her ne kadar bazı istisnalar olsa da İslâm dünyasının bu özgün kurumu hakkında yeterli ve yetkin araştırmalar sınırlıdır. İslâm eğitim, bilim ve felsefesine ilişkin derinlikli, güvenilir metot ve kaynak verilerle bilim dünyasına anlamlı katkı verici çalışmalar Batı dünyası tarafından yapılmaktadır. Örneğin, medrese tarihi hakkında hâlâ George Makdisi'nin Ortaçă̆da Yükseköğretim kitabından daha iyisini göstermek biraz güçtür.

$\mathrm{Bu}$ yazıda Osmanlı öncesi döneme denk gelen Şam medreselerini (11901350) göz kamaştıran bir titizlik ve ciddiyetle soğukkanlı biçimde araştıran Amerikalı araştırmacı Michael Chamberlain'in Ortaçağgda Bilgi ve Sosyal Pratik başlıklı kitabı tetkik edilmektedir. 
Kitap medrese, İslâmî ilimler ve Müslümanlar, yöneticiler ve toplumsal hayatın işleyişi ve eğitim mekânları gibi konularda alışılmışın dışında şaşırtıcı bilgiler eşliğinde yorumlar vermektedir. Kitaptaki konu-yazar bütünleşmesine bakıldığında, Chamberlain'in 1200'lü yılların Şam medreselerinin birinde okumuş, âyân ile sofraya oturmuş, bir yargılama içtimaına katılmış, halkla kaynaşmış, araştırdığı zaman ve mekânın kılcal damarlarında gezinen biri olduğu zannedilir.

Kitap yönetici sınıf ve medresenin var olma gerekçesi hakkında sıra dışı bir yorum yapmıştır. Daha da önemlisi, özellikle Ortadoğu Müslüman dünyasının yönetim, ilim, yönetici ve toplum sisteminin mevcut dağınıklık ve nahoş manzarasının binli yıllara kadar uzanan köklerine işaret etmektedir. Yazar araştırmasının temel amacını, "mülkiyetin güçlükle kontrol edebildiği çalkantılı bir döneme daha çok bir mansıp alabilmek için mücadele eden sivil elitler (âyân) bilgiyle (el-ilm) yakın ilişkini, kültürel pratiklerin sosyal devamlılıklarını teminde nasıl kullandıklarını sorgulamak" (s. 24) olarak belirlemiştir.

Yazarın merak ettiği temel mesele, ortaçağda ilim tahsilinin yöneticiler ve sıradan insanlar için faydasının ne olduğu sorusudur. Şam âyânının 160 yıllık bir dönemde bilgiyi elde etme ve onu sosyal devamlılıklarında kullanma şekillerini araştırmak için şu sorulara cevap aramaktadır: Âyân aileleri kendilerini nasıl yeniden üretebilmişlerdir? Âyân sadakati ve kültürel üstünlüğü hangi araçlarla kazanabilmiştir? Birbiriyle rekabet ederken başvurdukları pratikler nelerdir? Sosyal dünyayı nasıl tahayyül ediyorlar ve kendilerini bu dünyanın içinde nasıl konumlandırıyorlardı?

Her ne kadar o dönemden zamanımıza çok az orijinal belge ulaşmışsa da, yazar kaynak olarak, seyahatnameler, kronikler, tabakât kitapları, binalar, sokak planları, kitabeler, madenî paralar, memur ve kâtipler için yazılmış kılavuz ve risaleleri dikkatle incelemiş görünmektedir. Kitabın yöntem ve kaynaklar kısmı ortalama okuyucular için hayli sıkıcı ve uzundur. Kitapta sınırlı da olsa özel bir yöntem denenmiş ve ilgili tarihte Şam'daki durum Batı Latin dünyası ve Çin ile kıyas edilmiştir. Bu karşılaştırmanın avantaj ve sınırlılıkları anlatılmıştır (s. 42 vd.).

Kitap beş bölümden oluşmaktadır ve her bölüm sıkıca birbiriyle ilgilidir. İlk bölümde, âyânın kim olduğu ve Şam âyânının kimlerden oluştuğu sorusuna cevap aranırken, idareciler, askerler ve şehrin tabii sosyal yapısı ve dönüşümüyle bu süreçte vakıfların/medreselerin ortaya çıkış sebebi ve sahipleri anlatılmıştır. İkinci bölümde ise şu sualler dile getirilmiştir: Şam'da bilginin aktarımıyla aile vakıflarının kurduğu medreselerin çoğalması arasında nasıl bir ilişki vardır? Medreseler 
seçkinlerin (Şam âyânı) sosyal ve siyasî stratejilerine nasıl hizmet etmiştir? Üçüncü bölümde şehirde çok sayıda aile vakfı kurmanın âyân açısından sonuçları incelenmiştir. "Kültürel Sermaye" başlıklı dördüncü bölümde yönetici elitin ilmi nasıl hayat pratiği haline getirip bunu sürekli kılma yolları denediği anlatılmıştır. Son bölümde, âlimler ve askerler davranışlar, karakterler ve roller bakımından sıradışı bir şekilde karşılaştırılmıştır.

İlk bölümde temel kavramları açıkladıktan sonra yazar, Şam'da yönetici elit ve vakıf ilişkisini incelemiştir. Bilinenlerin ötesinde vakıf kurmanın gerekçeleri izah edilmiş ve vakıfların ideolojik araç olarak görülmediğini belirtmiştir. Ancak vakıflara bağlı medreselerin en önemli mansıp mekânı olduğuna sürekli vurgu yapılmıştır. Bu yapı devletten faydalanmak isteyenler için daimi bir savaş alanı olmuştur. Zira mansıp elde etmek çoğu zaman performans odaklı değildir. Zira Ortaçağ Şam'ında ne meritokrasiye dayalı bir istihdam ne de profesyonellerden oluşmuş bir bürokratik terfi sistemi vardır (s. 58). Buna karşın özellikle sivil elitlerin yönetim meşruiyetini tesis ve bir çeşit sosyal onur kazanımı (s. 89) için hem medrese kurdukları hem de ilim öğrendikleri temel iddialarından biridir.

Kitabın ilginç tezlerinden biri Şam medreselerinin Batı tipi üniversite ile mukayese edilemeyeceğidir. Yazara göre medrese bir yükseköğretim sisteminin parçası değildir. Çünkü medresenin özel, ayrıcalıklı bir müfredatı yoktur. Medrese ortak kimliğe veya örgütlenmeye sahip değildir, medreseye devam etmek seçkin statülerin aktarılmasında rol sağlamaz (s. 101). Yazar bu iddialarını ikna edici bilgi ve üslupla bolca örnekler vererek ispat etmektedir. Özgün örneklerden biri, mezuniyet belgesiyle ilgilidir: Medresede "icazet" hoca/âlim tarafından verilir. Batı dünyasında ise Licentia docendi tüzel kişilik sahibi üniversite tarafından verilir. Bu bakımdan medrese Latin üniversitelerinden farklıdır.

$\mathrm{Bu}$ günün memuriyeti diyebileceğimiz mansıp, ortaçağ devletlerinde en kolay ve en yüksek düzeyde kazanç sağlama yollarından biridir. Dolayısıyla mansıp rekabeti, büyük nüfuzlu aileler ve üst düzey memurların şiddetli savaş arenası haline gelmiştir. Mansıp sahibi olmak zordur ve bir dizi strateji gerektirmektedir. Mansıba ulaşmanın en kestirme ve kolay yolu, -uzun bir süre istese de- eğitimdir (Bu gerçek yirmi birinci yüzyıl için de gerçekliğini aynen korumaktadır). İlimle uğraşanlar daima bu yarışın içindedir ve bilgileri sayesinde eğer iktidara yakın iseler iyi mansıplar elde edebilmekte, değilseler sürgünler, hapisler hatta ip ya da kılıç boyunlarını beklemektedir (s. 131 vd.). Her ne kadar teoride şöhret ve mansıp talebi zemmedilmiş ise de âlimler bu konuda çoklukla kendilerini bir yarışın 
ya da pazarlığın içinde bularak tutarsızlık göstermişler ve bazıları da bunu itiraftan geri kalmamıştır. İnsanların mansıpla karşı karşıya geldiklerinde yaşadıklarını ve kendinden kibarca nefret etme tecrübelerini İbnü’l-Hâc, şöyle dile getir: "Biz bu dünyaya ait şeyleri dilimizle küçümserken, onlara dört elle sarılıyoruz.” İbn Cemaa da takipçilerine çok talebe, ün, mansıp veya para elde etmek gibi dünyevî gayeler için ilim öğrenmemelerini tavsiye etse de kendisi ulemanın en dünyevî olanlarındandır ve Mısır ve Suriye'de pek çok mansıba sahiptir (s. 137).

Bu tezat durumdan sonra yazar, ilim öğrenmenin ve medreseye devam etmenin gayesini, yalnızca hocaların metinlerini öğretmen ve şerh etmek değil, girift bir yapının devralınması olarak açıklar. Bu yapı, davranış biçimleri, ahlâki teamül, görgü kuralları ve belirli biçimleri olan şahsî sunum türlerinin birleşmesinden oluşan adap mefhumu ve bir tür "sembolik sermaye"dir (s. 140).

İlim sayesinde yönetici elit önemli ilişkiler ağı ve sürekli kılınabilecek sosyal ayrıcalıklar elde etmektedir. Yazara göre başka toplumlarda bu kazanımların çoğu "kitap telifi" veya "yükseköğretim" gibi formel alanlara tahsis edilmişken Ortaçă̆ Şam’ında bunlar "basit ritüeller, taklide ve uygulama pratiklerine" (s. 141) dayalıdır. Bu iddialar, talebe hoca arası ilişkiler, şahsa ve ailesine hürmet, muhabbet, sohbet, ziyaret, hizmet gibi olgular üzerinden takip edilir. Farklı taklit örneklerine değinilir.

"Bilginin ritüelleşmesi başlı̆̆ında", ilim ve temizlik ilişkisi, kirliliğin yerilmesi, kalem, kâğıt, mürekkep ve kitabın kutsiyeti, bazı mesleklerin men edilmesi, ilim talebinin ibadet görülmesi, talebenin oturma düzeni ve ilim öğrenmede kurallar özgün örnekler verilerek anlatılmıştır (s. 162-167). Yazar, okuma yazma olgusu üzerine de orijinal örnekler vermiştir. Kitap seçkinler için ayrıcalıktır, yönetici için ezber gerekli ve seçkinci bir sermayedir, kitap bilgiden değil hocadan öğrenilir, zira kitap aynı zamanda tüm bozucu unsurların en tehlikelilerindendir (s. 177). Kitaba bu kadar değer veren bir kültürel yapı içinde yazılı metne şüpheyle yaklaşılması büyük bir paradokstur. Buna karşın şifâhî aktarım silsileyi doğrudan Hazreti Peygamber'e bağlama gücü verir ve bu süreçte ezber önemli bir iş olarak görülür. Âlimleri nakzeden ve haddi aşan dîvaneler çıksa da onlar zımnen ilmin sosyal düzenle olan ilişkisini onaylamaktadır. Yazara göre bütün bunlar, sistemli bir yükseköğretim biçiminden ziyade, bir takım ritüel ve girişimci uygulamalardır.

"Hata, isabet ve sosyal iktidar mücadelesi” başlı̆̆ında anlatılanlar ise gerçekten ilginçtir. Tabâkat kitaplarının âlimleri tek kelimelik iltifat ve itibar cümleleriyle derecelendirdiği ve bu onursal iltifatın sosyal avantajlara dönüştüğü gösterilir. 
İlim dünyasında sadece insanlar değil, nesneler de derecelendirilir. Ders halkasındaki protokol, yerleşik kurallara muhalefetin bazen imtiyaz veren, bazen de utanç getirmesinin ilginç örnekleri gösterilir. Sahih ve fâsitin temyizi için münazara en etkin araçtır ve âlimler için bir "arena"dır (s. 212). Bu öyle bir arenadır ki, Makdisi münazara yapanları vahşi batıdaki düelloculara benzetmiştir. Bu tasvirde "kılıç metaforu" başta olmak üzere savaş sözcükleri ve davranış biçimleri, olguları sıklıkla kullanılır. Zira ilmî münazara neticesinde ödül, terfi, yüksek mansıp bir tarafta iken, diğer yanda sürgün, kürek hatta ölüm cezası bile verilebilmektedir. Çünkü münazarayı kaybeden aynı zamanda fasit, yalancı, sapık gibi konumların temsilcisi durumuna düşebilmektedir. Dolayısıyla âlimlerin mücadeleleri ile savaş meydanındaki mücahitlerin mücadeleleri yalnızca mecaz olarak kalmamakta, bir gerçekliğe dönüşebilmektedir. Ancak kültürel çatışmada siyasî olanla, içtimâ̂ olanı fark etmek "hakikat ile çıkarın birbirlerinin içine karşılıklı olarak işlemesini" fark etmekten elbette daha kolaydır.

Chamberlain kitabın özetini ve tezini sonuç kısmında kısaca ama kuşatıcı ve hayret verici bir tarzda yeniden anlatmıştır. Ona göre aslında Ortaçă̆ Suriye’sinde ihtisaslaşmış kurumlar, devlet daireleri yahut sınırları belirlenmiş kamu oluşumlarından bahsedilemez (s. 223). Orada güç, ayrıma tabi tutulmuş değildir. Gücü elinde tutan, devlet yahut kamu yapısı değil esasen büyük seçkin ailelerdir. Onlar gücün sosyal, siyasî ve ekonomik bütün veçhelerini ellerinde bulundurmaktadırlar. Vakıflar, medreseler büyük ölçüde söz konusu bütünün mütemmim cüzleridir. Şam ve çevresinde eğitim gibi bir sistemi organize etme gücüne sahip bağımsız yapılar yoktur ve dolayısıyla, bir "eğitim sistemi"nden de bahsetme imkanı söz konusu değildir.

Kitabın ilginç neticelerinden biri de, Şam'da medreselerin, sivil elit ve az sayıdaki zenginin ailenin mülkiyeti uzun süre ellerinde tutması için bir araç olarak kullanılmaları iddiasıdır. Âyân için medrese, kendi mücadelelerinin kazanımlarını elde ettikleri, sert mücadelelerin verildiği bir tür arenadır. Yine de medreseler, kurumsal bir elit yaratmak yahut yetiştirmek yerine nispeten bürokratik elitler üretebilmiştir. Medreseler, devletin kendi çekirdek kadrosunu yetiştirdiği yahut sivil elitlerin sosyal ve kültürel sermayelerini sonraki nesillerine aktardığı araçlar da değildir. Aksine medreseler sivil elit için mansıp, mesken ve birbirleriyle iletişim kurdukları bir ortamdır.

Yazar, George Makdisi'nin aksine, medreseleri kurumsallaşmış bir eğitim sistemi olarak görmez. Ona göre Şam’da değil bir “eğitim sistemi”nden, formel 
olsun olmasın ihtisaslaşmış bir eğitim ortamından bahsetmek dahi zordur (s. 225). Okullarda ihtisaslaşmış eğitimin varlığını gösteren hiçbir delil yoktur. Resmî kurumlar sayesinde elde edilen hususi bir kültür biçimi de yoktur. $\mathrm{O}$ dönemde bilginin aktarımı yalnızca okullara yahut gençlik dönemine has değildir. Yüksek kültürün başlıca şeklî unsuru, bilgi üretimi ve onun yaygın biçimde dağılımıydı ki buna gençler de dâhil oluyordu. Toplumda bunu bir "eğitim sistemi" olarak ele almak, âyânın hayatları boyunca bilgiyi nasıl edindiğini ve kullandığını gözden kaçırmak demektir.

Kitap biterken yazarın kurduğu cümle, bu günden 1200'lere uzanan ince ama canlı ve acıtıcı bir sürekliliğe işaret etmesi bakımından hayli manidardır: eğitim sisteminin adil, hasbî ve eşitlikçi bir şekilde bilgi üretmek ve aktarmak misyonundan ziyade örtülü olarak yönetme ve sınıf atlama kanalı olarak araçsallaştırılması bin yıllık tarihte olduğu gibi "bu günün Ortadoğu, Asya, Avrupa ve Amerika’sındaki Müslüman grupların bilgi aktarımı için de geçerlidir.”

$\mathrm{Bu}$ enteresan bulgularıla Ortaçağgda Bilgi ve Sosyal Pratik medrese tarihinin klasiklerinden biridir. Ancak unutulmaması gereken önemli bir husus var: İslam dünyasının hemen her yüzyılında ve her farklı coğrafyasındaki medrese sistemi birbirinden farklıdır. Dolayısıyla da bu kitabın, Şam gibi hususî bir yere odaklandığı, oranın sosyo-kültürel ve coğrafî nitelikleriyle doğrudan ilgili olduğu hatırdan çıkarılmamalıdır. Elbette diğer büyük İslam şehirlerindeki medrese, ilim, âlim ve içtimai hayat gibi mevzuları tecessüs de her ilim yolcusunun vazifesi olmalıdır.

Mustafa Gündüz

Yıldız Teknik Üniversitesi 